\title{
Reflexiones acerca de las peculiaridades de la enseñanza de las Ciencias Naturales en grados agrupados de Escuelas Rurales
}

\author{
Galfrascoli, Adrián
}

\section{Resumen}

En este artículo reflexionamos sobre la forma de organizar la enseñanza de las ciencias naturales en grados agrupados rurales. Partimos reconociendo que la enseñanza en las escuelas se organizó bajo un principio de gradualidad y de simultaneidad que se instaló y se naturalizó configurando una gramática escolar ampliamente difundida. Es posible identificar este dispositivo en la forma de organización de las escuelas urbanas con estudiantes agrupados en clases homogéneas, cada una con un grado de dificultad específico, en base a su edad. Avanzamos exponiendo que los docentes en ejercicio intentan extrapolar este tipo de configuración a la enseñanza de las ciencias en los ámbitos rurales a pesar de que no responde a la heterogeneidad del grupo de estudiantes que lo caracteriza. Sostenemos que el estímulo a la investigación sobre la didáctica de la ciencia en grados agrupados y la reflexión y el debate fecundos en las Institutos Superiores sobre las adecuaciones necesarias para enseñar en plurigrado contribuirían en la elaboración de un conocimiento didáctico específico para este contexto desde el que se podría diseñar, desarrollar y evaluar secuencias de enseñanza de las ciencias naturales específicas para el aula rural. Finalizamos delineando una posible forma de intervención para este contexto.

Palabras clave: enseñanza de las Ciencias Naturales, plurigrado, ruralidad.

Presentado: 10-8-13 | Aceptado: 2-10-13

Institución: Instituto Superior de Profesorado $N^{\circ} 4$,

Reconquista, Santa Fe, Argentina.

Calle 302, № 108, Avellaneda,

Santa Fe. Cp. 3561

agalfrascoli@educ.ar 


\section{Summary}

\section{Reflections about the peculiarities of the degrees in natural science education grouped rural schools}

In this article we reflect about the way to organized the teaching of Natural Sciences in rural grouped forms. From the very beginning, we recognized that teaching in the schools was organized under a graduated and simultaneous principle that was set out and became naturalized creating a school grammar widely spread. This device is identified in the way of organization of the urban schools with students grouped in homogeneous classes, each one with a different degree of difficulty, according to their age. We go on explaining that the current teachers try to extrapolate this type of configuration to the teaching of Natural Sciences in the rural areas despite it doesn't correspond to the heterogeneity of the group of students. We support that the stimulus to investigation about the didactics of science in grouped forms and the reflection and the debate in Teacher Training Colleges about the necessary adequacies to teach in a mixed aged class, will help in the elaboration of a didactic specific knowledge to this context from which it could be possible to design, develop and evaluate teaching sequences for Natural Science classes specific to the rural form. Finally, we draw a possible way of intervention to this context.

Keywords: teaching of Natural Sciences, rural grouped forms, rural areas. 